\title{
Definition of Terms Used in the National Organic Program 1
}

James J. Ferguson ${ }^{2}$

The National Organic Program (NOP) under the direction of the Agricultural Marketing Service, United States Department of Agriculture was established to "facilitate domestic and international marketing of fresh and processed food that is organically produced and assure consumers that such products meet consistent, uniform standards." The final rule of the National Organic Program covers production, packing and processing, marketing, retailing, and other aspects of organic operations. Given the complexity of regulatory aspects of the National Organic Program, a set of definitions (107 terms) has been developed to clarify the meaning of specific words and phrases and can be found at http://www.ams.usda.gov/nop/NOP/standards/ DefineReg.html. This set of definitions, taken directly from the above web site, is included here to make this information more easily accessible.

\section{Definition of Terms}

Accreditation. A determination made by the Secretary that authorizes a private, foreign, or State entity to conduct certification activities as a certifying agent under this part.
Act. The Organic Foods Production Act of 1990, as amended (7 U.S.C. 6501 et seq.).

Action level. The limit at or above which the Food and Drug Administration will take legal action against a product to remove it from the market. Action levels are based on unavoidability of the poisonous or deleterious substances and do not represent permissible levels of contamination where it is avoidable.

Administrator. The Administrator for the Agricultural Marketing Service, United States Departure of Agriculture, or the representative to whom authority has been delegated to act in the stead of the Administrator.

Agricultural inputs. All substances or materials used in the production or handling of organic agricultural products.

Agricultural product. Any agricultural commodity or product, whether raw or processed, including any commodity or product derived from livestock, that is marketed in the United States for human or livestock consumption.

1. This document is HS963, one of a series of the Horticultural Sciences Department, Florida Cooperative Extension Service, Institute of Food and Agricultural Sciences, University of Florida. Publication date: January 2004. Please visit the EDIS Web site at http://edis.ifas.ufl.edu.

2. James J. Ferguson, professor, Horticultural Sciences Department, Cooperative Extension Service, Institute of Food and Agricultural Sciences, University of Florida, Gainesville, 32611.

The Institute of Food and Agricultural Sciences (IFAS) is an Equal Employment Opportunity - Affirmative Action Employer authorized to provide research, educational information and other services only to individuals and institutions that function without regard to race, creed, color, religion, age, disability, sex, sexual orientation, marital status, national origin, political opinions or affiliations. For information on obtaining other extension publications, contact your county Cooperative Extension Service office. Florida Cooperative Extension Service / Institute of Food and Agricultural Sciences / University of Florida / Larry R. Arrington, Interim Dean 
Allowed synthetic. A substance that is included on the National List of synthetic substances allowed for use in organic production or handling.

Agricultural Marketing Service (AMS). The Agricultural Marketing Service of the United States Department of Agriculture.

Animal drug. Any drug as defined in section 201 of the Federal Food, Drug, and Cosmetic Act, as amended (21 U.S.C. 321), that is intended for use in livestock, including any drug intended for use in livestock feed but not including such livestock feed.

Annual seedling. A plant grown from seed that will complete its life cycle or produce a harvestable yield within the same crop year or season in which it was planted.

Area of operation. The types of operations: crops, livestock, wild-crop harvesting or handling, or any combination thereof that a certifying agent may be accredited to certify under this part.

Audit trail. Documentation that is sufficient to determine the source, transfer of ownership, and transportation of any agricultural product labeled as "100 percent organic," the organic ingredients of any agricultural product labeled as "organic" or "made with organic (specified ingredients)" or the organic ingredients of any agricultural product containing less than 70 percent organic ingredients identified as organic in an ingredients statement.

Biodegradable. Subject to biological decomposition into simpler biochemical or chemical components.

Biologics. All viruses, serums, toxins, and analogous products of natural or synthetic origin, such as diagnostics, antitoxins, vaccines, live microorganisms, killed microorganisms, and the antigenic or immunizing components of microorganisms intended for use in the diagnosis, treatment, or prevention of diseases of animals.

Breeder stock. Female livestock whose offspring may be incorporated into an organic operation at the time of their birth.
Buffer zone. An area located between a certified production operation or portion of a production operation and an adjacent land area that is not maintained under organic management. A buffer zone must be sufficient in size or other features (e.g., windbreaks or a diversion ditch) to prevent the possibility of unintended contact by prohibited substances applied to adjacent land areas with an area that is part of a certified operation.

Bulk. The presentation to consumers at retail sale of an agricultural product in unpackaged, loose form, enabling the consumer to determine the individual pieces, amount, or volume of the product purchased.

Certification or certified. A determination made by a certifying agent that a production or handling operation is in compliance with the Act and the regulations in this part, which is documented by a certificate of organic operation.

Certified operation. A crop or livestock production, wild-crop harvesting or handling operation, or portion of such operation that is certified by an accredited certifying agent as utilizing a system of organic production or handling as described by the Act and the regulations in this part.

Certifying agent. Any entity accredited by the Secretary as a certifying agent for the purpose of certifying a production or handling operation as a certified production or handling operation.

Certifying agent's operation. All sites, facilities, personnel, and records used by a certifying agent to conduct certification activities under the Act and the regulations in this part.

Claims. Oral, written, implied, or symbolic representations, statements, or advertising or other forms of communication presented to the public or buyers of agricultural products that relate to the organic certification process or the term, " 100 percent organic," "organic," or "made with organic (specified ingredients or food group(s))," or, in the case of agricultural products containing less than 70 percent organic ingredients, the term, "organic," on the ingredients panel. 
Commercially available. The ability to obtain a production input in an appropriate form, quality, or quantity to fulfill an essential function in a system of organic production or handling, as determined by the certifying agent in the course of reviewing the organic plan.

Commingling. Physical contact between unpackaged organically produced and nonorganically produced agricultural products during production, processing, transportation, storage or handling, other than during the manufacture of a multiingredient product containing both types of ingredients.

Compost. The product of a managed process through which microorganisms break down plant and animal materials into more available forms suitable for application to the soil. Compost must be produced through a process that combines plant and animal materials with an initial C:N ratio of between 25:1 and 40:1. Producers using an in-vessel or static aerated pile system must maintain the composting materials at a temperature between $131^{\circ} \mathrm{F}$ and $170^{\circ} \mathrm{F}$ for 3 days. Producers using a windrow system must maintain the composting materials at a temperature between $131^{\circ} \mathrm{F}$ and $170^{\circ} \mathrm{F}$ for 15 days, during which time, the materials must be turned a minimum of five times.

Control. Any method that reduces or limits damage by populations of pests, weeds, or diseases to levels that do not significantly reduce productivity.

Crop. A plant or part of a plant intended to be marketed as an agricultural product or fed to livestock.

Crop residues. The plant parts remaining in a field after the harvest of a crop, which include stalks, stems, leaves, roots, and weeds.

Crop rotation. The practice of alternating the annual crops grown on a specific field in a planned pattern or sequence in successive crop years so that crops of the same species or family are not grown repeatedly without interruption on the same field. Perennial cropping systems employ means such as alley cropping, intercropping, and hedgerows to introduce biological diversity in lieu of crop rotation.
Crop year. That normal growing season for a crop as determined by the Secretary.

Cultivation. Digging up or cutting the soil to prepare a seed bed; control weeds; aerate the soil; or work organic matter, crop residues, or fertilizers into the soil.

Cultural methods. Methods used to enhance crop health and prevent weed, pest, or disease problems without the use of substances; examples include the selection of appropriate varieties and planting sites; proper timing and density of plantings; irrigation; and extending a growing season by manipulating the microclimate with green houses, cold frames, or wind breaks.

Detectable residue. The amount or presence of chemical residue or sample component that can be reliably observed or found in the sample matrix by current approved analytical methodology.

Disease vectors. Plants or animals that harbor or transmit disease organisms or pathogens which may attack crops or livestock.

Drift. The physical movement of prohibited substances from the intended target site onto an organic operation or portion thereof.

Emergency pest or disease treatment program. A mandatory program authorized by a Federal, State, or local agency for the purpose of controlling or eradicating a pest or disease.

Employee. Any person providing paid or volunteer services for a certifying agent.

Excluded methods. A variety of methods used to genetically modify organisms or influence their growth and development by means that are not possible under natural conditions or processes and are not considered compatible with organic production. Such methods include cell fusion, microencapsulation and macroencapsulation, and recombinant DNA technology (including gene deletion, gene doubling, introducing a foreign gene, and changing the positions of genes when achieved by recombinant DNA technology). Such methods do not include the use of traditional breeding, conjugation, 
fermentation, hybridization, in vitro fertilization, or tissue culture.

Feed. Edible materials which are consumed by livestock for their nutritional value. Feed may be concentrates (grains) or roughages (hay, silage, fodder). The term, "feed," encompasses all agricultural commodities, including pasture ingested by livestock for nutritional purposes.

Feed additive. A substance added to feed in micro quantities to fulfill a specific nutritional need; i.e., essential nutrients in the form of amino acids, vitamins, and minerals.

Feed Supplement. A combination of feed nutrients added to livestock feed to improve the nutrient balance or performance of the total ration and intended to be:

- diluted with other feeds when fed to livestock

- offered free choice with other parts of the ration if separately available

- further diluted and mixed to produce a complete feed

Fertilizer. A single or blended substance containing one or more recognized plant nutrient(s) which is used primarily for its plant nutrient content and which is designed for use or claimed to have value in promoting plant growth.

Field. An area of land identified as a discrete unit within a production operation.

Forage. Vegetative material in a fresh, dried, or ensiled state (pasture, hay, or silage), which is fed to livestock.

Governmental entity. Any domestic government, tribal government, or foreign governmental subdivision providing certification services.

Handle. To sell, process, or package agricultural products, except such term shall not include the sale, transportation, or delivery of crops or livestock by the producer thereof to a handler.
Handler. Any person engaged in the business of handling agricultural products, including producers who handle crops or livestock of their own production, except such term shall not include final retailers of agricultural products that do not process agricultural products.

Handling operation. Any operation or portion of an operation (except final retailers of agricultural products that do not process agricultural products) that receives or otherwise acquires agricultural products and processes, packages, or stores such products.

Immediate family. The spouse, minor children, or blood relatives who reside in the immediate household of a certifying agent or an employee, inspector, contractor, or other personnel of the certifying agent. For the purpose of this part, the interest of a spouse, minor child, or blood relative who is a resident of the immediate household of a certifying agent or an employee, inspector, contractor, or other personnel of the certifying agent shall be considered to be an interest of the certifying agent or an employee, inspector, contractor, or other personnel of the certifying agent.

Inert ingredient. Any substance (or group of substances with similar chemical structures if designated by the Environmental Protection Agency) other than an active ingredient which is intentionally included in any pesticide product (40 CFR 152.3(m)).

Information panel. That part of the label of a packaged product that is immediately contiguous to and to the right of the principal display panel as observed by an individual facing the principal display panel, unless another section of the label is designated as the information panel because of package size or other package attributes (e.g., irregular shape with one usable surface).

Ingredient. Any substance used in the preparation of an agricultural product that is still present in the final commercial product as consumed.

Ingredients statement. The list of ingredients contained in a product shown in their common and usual names in the descending order of predominance. 
Inspector. Any person retained or used by a certifying agent to conduct inspections of certification applicants or certified production or handling operations.

Inspection. The act of examining and evaluating the production or handling operation of an applicant for certification or certified operation to determine compliance with the Act and the regulations in this part.

Label. A display of written, printed, or graphic material on the immediate container of an agricultural product or any such material affixed to any agricultural product or affixed to a bulk container containing an agricultural product, except for package liners or a display of written, printed, or graphic material which contains only information about the weight of the product.

Labeling. All written, printed, or graphic material accompanying an agricultural product at any time or written, printed, or graphic material about the agricultural product displayed at retail stores about the product.

Livestock. Any cattle, sheep, goat, swine, poultry, or equine animals used for food or in the production of food, fiber, feed, or other agricultural-based consumer products; wild or domesticated game; or other nonplant life, except such term shall not include aquatic animals or bees for the production of food, fiber, feed, or other agricultural-based consumer products.

Lot. Any number of containers which contain an agricultural product of the same kind located in the same conveyance, warehouse, or packing house and which are available for inspection at the same time.

Manure. Feces, urine, other excrement, and bedding produced by livestock that has not been composted.

Market information. Any written, printed, audiovisual, or graphic information, including advertising, pamphlets, flyers, catalogues, posters, and signs, distributed, broadcast, or made available outside of retail outlets that are used to assist in the sale or promotion of a product.
Mulch. Any nonsynthetic material, such as wood chips, leaves, or straw, or any synthetic material included on the National List for such use, such as newspaper or plastic that serves to suppress weed growth, moderate soil temperature, or conserve soil moisture.

Narrow range oils. Petroleum derivatives, predominately of paraffinic and napthenic fractions with 50 percent boiling point $(10 \mathrm{~mm} \mathrm{Hg})$ between $415 \mathrm{~F}$ and $440 \mathrm{~F}$.

National List. A list of allowed and prohibited substances as provided for in the Act.

National Organic Program (NOP). The program authorized by the Act for the purpose of implementing its provisions.

National Organic Standards Board (NOSB). A board established by the Secretary under 7 U.S.C. 6518 to assist in the development of standards for substances to be used in organic production and to advise the Secretary on any other aspects of the implementation of the National Organic Program.

Natural resources of the operation. The physical, hydrological, and biological features of a production operation, including soil, water, wetlands, woodlands, and wildlife.

Nonagricultural substance. A substance that is not a product of agriculture, such as a mineral or a bacterial culture, that is used as an ingredient in an agricultural product. For the purposes of this part, a nonagricultural ingredient also includes any substance, such as gums, citric acid, or pectin, that is extracted from, isolated from, or a fraction of an agricultural product so that the identity of the agricultural product is unrecognizable in the extract, isolate, or fraction.

Nonsynthetic (natural). A substance that is derived from mineral, plant, or animal matter and does not undergo a synthetic process as defined in section 6502(21) of the Act (7 U.S.C. 6502(21)). For the purposes of this part, nonsynthetic is used as a synonym for natural as the term is used in the Act. 
Nontoxic. Not known to cause any adverse physiological effects in animals, plants, humans, or the environment.

Nonretail container. Any container used for shipping or storage of an agricultural product that is not used in the retail display or sale of the product.

Organic. A labeling term that refers to an agricultural product produced in accordance with the Act and the regulations in this part.

Organic matter. The remains, residues, or waste products of any organism.

Organic production. A production system that is managed in accordance with the Act and regulations in this part to respond to site-specific conditions by integrating cultural, biological, and mechanical practices that foster cycling of resources, promote ecological balance, and conserve biodiversity.

Organic system plan. A plan of management of an organic production or handling operation that has been agreed to by the producer or handler and the certifying agent and that includes written plans concerning all aspects of agricultural production or handling described in the Act and the regulations in subpart $\mathrm{C}$ of this part.

Pasture. Land used for livestock grazing that is managed to provide feed value and maintain or improve soil, water, and vegetative resources.

Peer review panel. A panel of individuals who have expertise in organic production and handling methods and certification procedures and who are appointed by the Administrator to assist in evaluating applicants for accreditation as certifying agents.

Person. An individual, partnership, corporation, association, cooperative, or other entity.

Pesticide. Any substance which alone, in chemical combination, or in any formulation with one or more substances is defined as a pesticide in section 2(u) of the Federal Insecticide, Fungicide, and Rodenticide Act (7 U.S.C. 136(u) et seq).
Petition. A request to amend the National List that is submitted by any person in accordance with this part.

Planting stock. Any plant or plant tissue other than annual seedlings but including rhizomes, shoots, leaf or stem cuttings, roots, or tubers, used in plant production or propagation.

Practice standard. The guidelines and requirements through which a production or handling operation implements a required component of its production or handling organic system plan. A practice standard includes a series of allowed and prohibited actions, materials, and conditions to establish a minimum level performance for planning, conducting, and maintaining a function, such as livestock health care or facility pest management, essential to an organic operation.

Principal display panel. That part of a label that is most likely to be displayed, presented, shown, or examined under customary conditions of display for sale.

Private entity. Any domestic or foreign nongovernmental for-profit or not-for-profit organization providing certification services.

Processing. Cooking, baking, curing, heating, drying, mixing, grinding, churning, separating, extracting, slaughtering, cutting, fermenting, distilling, eviscerating, preserving, dehydrating, freezing, chilling, or otherwise manufacturing and includes the packaging, canning, jarring, or otherwise enclosing food in a container.

Processing aid. (a) substance that is added to a food during the processing of such food but is removed in some manner from the food before it is packaged in its finished form; (b) a substance that is added to a food during processing, is converted into constituents normally present in the food, and does not significantly increase the amount of the constituents naturally found in the food; and (c) a substance that is added to a food for its technical or functional effect in the processing but is present in the finished food at insignificant levels and does not have any technical or functional effect in that food. 
Producer. A person who engages in the business of growing or producing food, fiber, feed, and other agricultural-based consumer products.

Production lot number/identifier. Identification of a product based on the production sequence of the product showing the date, time, and place of production used for quality control purposes.

Prohibited substance. A substance the use of which in any aspect of organic production or handling is prohibited or not provided for in the Act or the regulations of this part.

Records. Any information in written, visual, or electronic form that documents the activities undertaken by a producer, handler, or certifying agent to comply with the Act and regulations in this part.

Residue testing. An official or validated analytical procedure that detects, identifies, and measures the presence of chemical substances, their metabolites, or degradations products in or on raw or processed agricultural products.

Responsibly connected. Any person who is a partner, officer, director, holder, manager, or owner of 10 percent or more of the voting stock of an applicant or a recipient of certification or accreditation.

Retail food establishment. A restaurant; delicatessen; bakery; grocery store; or any retail outlet with an in-store restaurant, delicatessen, bakery, salad bar, or other eat-in or carry-out service of processed or prepared raw and ready-to-eat-food.

Routine use of parasiticide. The regular, planned, or periodic use of parasiticides.

Secretary. The Secretary of Agriculture or a representative to whom authority has been delegated to act in the Secretary's stead.

Sewage sludge. A solid, semisolid, or liquid residue generated during the treatment of domestic sewage in a treatment works. Sewage sludge includes but is not limited to: domestic septage; scum or solids removed in primary, secondary, or advanced wastewater treatment processes; and a material derived from sewage sludge. Sewage sludge does not include ash generated during the firing of sewage sludge in a sewage sludge incinerator or grit and screenings generated during preliminary treatment of domestic sewage in a treatment works.

Slaughter stock. Any animal that is intended to be slaughtered for consumption by humans or other animals.

Split operation. An operation that produces or handles both organic and nonorganic agricultural products.

Soil and water quality. Observable indicators of the physical, chemical, or biological condition of soil and water, including the presence of environmental contaminants.

State. Any of the several States of the United States of America, its territories, the District of Columbia, and the Commonwealth of Puerto Rico.

State certifying agent. A certifying agent accredited by the Secretary under the National Organic Program and operated by the State for the purposes of certifying organic production and handling operations in the State.

State organic program (SOP). A State program that meets the requirements of section 6506 of the Act, is approved by the Secretary, and is designed to ensure that a product that is sold or labeled as organically produced under the Act is produced and handled using organic methods.

\section{State organic program's governing State} official. The chief executive official of a State or, in the case of a State that provides for the statewide election of an official to be responsible solely for the administration of the agricultural operations of the State, such official who administers a State organic certification program.

Synthetic. A substance that is formulated or manufactured by a chemical process or by a process that chemically changes a substance extracted from naturally occurring plant, animal, or mineral sources, except that such term shall not apply to substances created by naturally occurring biological processes. 
Tolerance. The maximum legal level of a pesticide chemical residue in or on a raw or processed agricultural commodity or processed food.

Transplant. A seedling which has been removed from its original place of production, transported, and replanted.

Unavoidable residual environmental contamination (UREC). Background levels of naturally occurring or synthetic chemicals that are present in the soil or present in organically produced agricultural products that are below established tolerances.

Wild crop. Any plant or portion of a plant that is collected or harvested from a site that is not maintained under cultivation or other agricultural management. 